\title{
Redaktioneller Hinweis
}

Auf Grund eines redaktionellen Versehens ist in LiLi 154 vom Juni 2009 der Beitrag » Literature of the Souk: Die Kafka-Rezeption der chinesischen Autorin Can Хие « von Roman Halfmann abgedruckt worden. Dieser Beitrag war jedoch zur Veröffentlichung in der Dezember-Ausgabe der Zeitschrift Orbis Litterarum bestimmt. Wir bitten, dieses Versehen, das nicht dem Autor anzulasten ist, zu entschuldigen. Zitierbar ist der Text ausschließlich nach der folgenden Quellenangabe:

Roman Halfmann »Literature of the Soul«. Die Kafka-Rezeption der chinesischen Autorin Can Xue. In: Orbis Litterarum, Volume 64, Issue 6, Date: December 2009, Pages: 478-499.

Ralf Schnell 